\title{
Peanut allergy and oral immunotherapy
}

\author{
TH Lee *, June KC Chan, PC Lau, WP Luk, LH Fung
}

\section{A B S T R A C T}

Peanut allergy is the commonest cause of foodinduced anaphylaxis in the world, and it can be fatal. There have been many recent improvements to achieve safe methods of peanut desensitisation, one of which is to use a combination of antiimmunoglobulin E and oral immunotherapy. We have treated 27 patients with anti-immunoglobulin $\mathrm{E}$ and oral immunotherapy, and report on the outcomes and incidence of adverse reactions encountered during treatment. The dose of peanut protein tolerated increased from a median baseline of 5 to $2000 \mathrm{mg}$ after desensitisation, which is substantially more than would be encountered through accidental ingestion. The incidence of adverse reactions during the escalation phase of oral immunotherapy was $1.8 \%$, and that during the maintenance phase was

This article was published on 10 Jun 2019 at www.hkmj.org.
$0.6 \%$. Most adverse reactions were mild; three episodes were severe enough to warrant withdrawal from oral immunotherapy, but none required epinephrine injection. Preliminary data suggest that unresponsiveness is lost when daily ingestion of peanuts is stopped after the maintenance period.

\section{Hong Kong Med J 2019;25:228-34}

https://doi.org/10.12809/hkmj187743

${ }^{1}$ TH Lee *, SCD, FRCP

${ }^{1}$ JKC Chan, MSc, RD (US)

${ }^{1}$ PC Lau, RN, BNurs

${ }^{2}$ WP Luk, MPhil

${ }^{2}$ LH Fung, MPhil

Allergy Centre, Hong Kong Sanatorium \& Hospital, Happy Valley, Hong Kong

${ }^{2}$ Medical Physics and Research, Hong Kong Sanatorium \& Hospital, Happy Valley, Hong Kong

* Corresponding author: takhong.lee@hksh.com

\section{Introduction}

Peanut is a leading food allergen alongside shellfish, eggs, milk, beef, and tree nuts. ${ }^{1}$ Strict peanut avoidance is difficult and stressful for patients and families. The incidence rates of accidental ingestion can be as high as $50 \%,{ }^{2,3}$ and it can cause anaphylaxis, which is sometimes fatal. Therefore, new management strategies for peanut allergy are required, such as oral immunotherapy (OIT).

\section{Peanut oral immunotherapy without anti-immunoglobulin $E$}

Most trials on peanut OIT have been conducted in the absence of anti-immunoglobulin E (anti-IgE) pretreatment.-10 These studies involve gradually increasing small doses of peanut (escalation phase) up to a maintenance dose of 300 to $4000 \mathrm{mg}$ peanut protein (PP), with or without a phase of rush immunotherapy when several doses were given on the same day at the start of OIT. The daily maintenance dose was then sustained for 6 months to 3 years. Peanut tolerance in subjects increased over time, and the tolerance to peanut in open food challenge (OFC) at completion of the treatment was often more than 2-fold greater than the daily maintenance intake. Efficacy of peanut OIT was high, where $67 \%$ to $93 \%$ of subjects were successfully desensitised to the maintenance dose. These studies have also been considered to demonstrate an acceptable degree of safety although there were dropouts in all the trials. Adverse reaction (AR) rates were $1.2 \%$ for build-up doses and 3.7\% to 6.3\% for home doses. Most ARs were oropharyngeal symptoms but there were some cases of anaphylaxis requiring epinephrine injection. In addition, eosinophilic gastroenteritis was a complication in some patients. In a recent peanut allergy OIT study using defatted slightly roasted peanut flour for desensitisation, $4.3 \%$ of children receiving peanut experienced severe ARs compared with $<1 \%$ of those receiving placebo; $21 \%$ of the peanut group withdrew from the study. ${ }^{10}$ Further, $14 \%$ of those ingesting peanut required epinephrine injection, including one child who experienced anaphylaxis and required three epinephrine injection, compared with $3.2 \%$ on placebo.

To sustain non-responsiveness following OIT, Tang et $\mathrm{al}^{7}$ used a combined therapy of probiotics and peanut OIT. The majority $(89.7 \%)$ of the probiotics and peanut OIT group were desensitised, and sustained unresponsiveness (SU) was achieved in $87.1 \%$ of the children, who could then consume peanuts ad libitum. A related follow-up study indicated that $58 \%$ of the probiotics and peanut OIT group subjects achieved 8-week SU at 4 years. ${ }^{8}$

\section{Peanut oral immunotherapy with anti-immunoglobulin $\mathrm{E}$}

Prior studies that have combined anti-IgE premedication with OIT are summarised in 
Table 1. ${ }^{11-14}$ In contrast to other studies, a study conducted in Hong Kong by Lee et $\mathrm{al}^{11}$ did not have a rush immunotherapy phase (when several doses of peanuts were administered on day 1); instead, peanut dose was increased more gradually at 2 -week intervals. Despite differences in study design, the outcomes from all the studies were similar. ${ }^{11-14}$ Lee et $\mathrm{al}^{11}$ found four children tolerated 466 to 4800 -fold more PP on OFC than before OIT; their threshold in peanut-specific skin prick tests increased by 10 - to 100-fold; and each subject's peanut allergen-specific IgG4 level increased after OIT. The prevalence of ARs in the study by Lee et $\mathrm{al}^{11}$ appeared to be lower than that first reported by Schneider et $\mathrm{al}^{12}$ using anti-IgE combined with OIT which included a rush immunotherapy step; however, the Hong Kong population included in the Lee et al study was small.

\section{花生過敏與口服脫敏治療}

\section{李德康、陳勁芝、劉佩芝、陸泳斌、馮凌曉}

花生過敏是目前最常見導致食物誘發過敏性休克的原因，而且可以致 命。近年, 花生脱敏治療研究的安全度已大有改進, 其中一個方案是 結合注射抗免疫球蛋白 $\mathrm{E}$ 和口服脱敏治療 (OIT)。此項研究中, 我 們為 27 名病人進行抗免疫球蛋白E注射和OIT結合治療, 並就治療結 果和期間不良反應的發生率進行報告。研究發現, 患者接受結合治療 後, 耐受花生蛋白的劑量中位數由 5 毫克提高至脱敏後 2000 毫克, 這 遠遠超於日常意外攝入劑量。在OIT劑量遞增期的不良反應發生率為 $1.8 \%$; 在劑量維持期的不良反應發生率為 $0.6 \%$ 。大多數不良反應屬於 輕微; 當中有三次出現嚴重過敏反應, 即使冊須注射腎上腺素但已令 患者退出OIT治療。初步數據顯示, 在劑量維持期後停止每天攝入花 生，對花生的耐受性就會失效。

TABLE I. Previous studies of peanut OIT with omalizumab

\begin{tabular}{|c|c|c|c|c|}
\hline $\begin{array}{l}\text { Authors, year, } \\
\text { and study type }\end{array}$ & Subjects & OIT design & Outcomes & ARs \\
\hline $\begin{array}{l}\text { Schneider et } \\
\text { al, } 2013 \text {, open } \\
\text { study }^{12}\end{array}$ & $\begin{array}{l}n=13, \text { aged } \\
8-16 \text { years }\end{array}$ & $\begin{array}{l}\text { - Omalizumab duration: } 20 \text { weeks } \\
\text { - OIT started at week } 12 \\
\text { - Rush protocol: } 6 \text { hrs (up to } 250 \text { mg } \\
\text { PP) } \\
\text { - Escalation: weekly to } 2000 \text { mg PP } \\
\text { (median } 20 \text { weeks) } \\
\text { - } 12 \text { weeks after stopping omalizumab: } \\
\text { DBPCFC of } 4000 \text { mg PP and if } \\
\text { tolerated ate } 10-20 \text { peanuts daily } \\
\text { until week } 52\end{array}$ & $\begin{array}{l}\text { - } 12 \text { subjects ( } 92 \%) \text { desensitised to } \\
2000 \text { mg PP daily } \\
\text { - } 11 \text { subjects }(85 \%) \text { passed DBPCFC of } \\
4000 \text { mg PP } \\
\text { - Peanut tolerance increase after OIT: } \\
\text { - } 160-400 \text { fold } \\
\text { - Increased PSIgG4 } \\
\text { - Decreased PSIgE }\end{array}$ & $\begin{array}{l}\text { - } 2 \% \text { of total peanut } \\
\text { doses during escalation } \\
\text { - } 5 \text { ARs required } \\
\text { epinephrine }\end{array}$ \\
\hline $\begin{array}{l}\text { Lee et al, } 2014 \text {, } \\
\text { open study }{ }^{11}\end{array}$ & $\begin{array}{l}\mathrm{n}=4, \text { aged } 8-12 \\
\text { years }\end{array}$ & $\begin{array}{l}\text { - Omalizumab duration: } 16-18 \text { weeks } \\
\text { - OIT started at week } 12 \\
\text { - Rush protocol: none, but with } \\
\text { DBPCFC to determine starting dose } \\
\text { - Escalation: bi-weekly to } 2000 \text { mg PP } \\
\text { ( } 25-31 \text { weeks) } \\
\text { - Maintenance: } 2000 \text { mg PP for } 36 \\
\text { months } \\
\text { - OFC } 6 \text { months after start of } \\
\text { maintenance: } 4800 \text { mg PP }\end{array}$ & $\begin{array}{l}\text { - } 100 \% \text { desensitised to } 2000 \text { mg PP } \\
\text { daily } \\
\text { - } 75 \% \text { tolerated } 4800 \text { mg PP and } 25 \% \\
\text { tolerated } 2800 \text { mg PP in DBPCFC } \\
\text { - Peanut tolerance increase after OIT: } \\
466-4800 \text { fold and 10-100 fold in the } \\
\text { peanut concentration that elicited a } \\
\text { positive SPT, respectively } \\
\text { - Increased PSlgG4 and decreased } \\
\text { PSlgE }\end{array}$ & $\begin{array}{l}\text { - } 0.2 \% \text { of total peanut } \\
\text { doses during escalation } \\
\text { - No epinephrine required }\end{array}$ \\
\hline $\begin{array}{l}\text { MacGinnitie } \\
\text { et al, } 2017, \\
\text { randomised } \\
\text { controlled trial }^{13}\end{array}$ & $\begin{array}{l}\mathrm{n}=37,8 \\
\text { placebo and } 29 \\
\text { omalizumab }\end{array}$ & $\begin{array}{l}\text { - Omalizumab duration: } 19 \text { weeks, } \\
\text { subjects who failed to tolerate } 1625 \\
\text { mg PP at week } 19 \text { received an extra } \\
\text { dose of omalizumab at week } 20 \\
\text { - OIT started at week } 12 \\
\text { - Rush protocol: } 1 \text { day (up to } 250 \text { mg } \\
\text { PP) } \\
\text { - Escalation: weekly to } 2000 \text { mg PP } \\
\text { (median } 20 \text { weeks) } \\
\text { - } 12 \text { weeks after stopping omalizumab: } \\
\text { DBPCFC of } 4000 \text { mg; if tolerated, } \\
\text { continued with } 4000 \text { mg PP daily; if } \\
\text { failed, challenge continued with } 2000 \\
\text { mg PP for an additional } 21 \text { weeks }\end{array}$ & $\begin{array}{l}\text { - } 23 \text { subjects }(79.3 \%) \text { in omalizumab } \\
\text { group tolerated } 2000 \text { mg PP } 6 \text { weeks } \\
\text { after withdrawal of omalizumab vs } 1 \\
\text { (12.5\%) in placebo group } \\
\text { - } 22 \text { subjects }(75.9 \%) \text { in omalizumab } \\
\text { group passed the } 4000 \text { mg OFC vs } 1 \\
\text { (12.5\%) in placebo group } \\
\text { - Peanut tolerance increase after OIT: } \\
\text { median } 105 \text { fold } \\
\text { - Decreased peanut SPT wheal size and } \\
\text { increased PSlgE }\end{array}$ & $\begin{array}{l}\text { AR rate similar between } \\
\text { omalizumab and } \\
\text { placebo groups; } 7.8 \% \\
\text { vs } 16.8 \% \text { of total doses } \\
\text { of PP in omalizumab } \\
\text { and placebo groups, } \\
\text { respectively } \\
\text { - } 4 \text { ARs vs } 3 \text { ARs } \\
\text { required epinephrine } \\
\text { in omalizumab and } \\
\text { placebo groups, } \\
\text { respectively }\end{array}$ \\
\hline $\begin{array}{l}\text { Yee et al, } 2019 \\
\text { open study }\end{array}$ & $\begin{array}{l}n=13, \text { aged } \\
8-16 \text { years }\end{array}$ & $\begin{array}{l}\text { Long-term follow-up study of Schneider } \\
\text { et al }{ }^{12} \text {; subjects received } 500 \text { to } 3500 \\
\text { mg PP for } 67 \text { months }\end{array}$ & $\begin{array}{l}\text { - Decreased peanut SPT PSIgE, Ara h1- } \\
\text { lgE, Ara h2-lgE, and PSIgE:IgE ratio } \\
\text { - PSIgG4, Ara h1-lgG4, and Ara } \\
\text { h2-lgG4 initially increased then } \\
\text { decreased } \\
\text { - } 6 \text { of } 13 \text { patients dropped out due to } \\
\text { AR. Patients who dropped out had } \\
\text { higher month } 12 \text { PSIgE and Ara h2- } \\
\text { lgE }\end{array}$ & $\begin{array}{l}12 \text { subjects had } 257 \text { ARs, } \\
\text { mostly mild; } 12 \text { of } 257 \\
\text { ARs required epinephrine }\end{array}$ \\
\hline
\end{tabular}

Abbreviations: $A R=$ adverse reaction; Ara $\mathrm{h}=$ Arachis hypogaea; DBPCFC = double-blind placebo-controlled food challenge; OFC = oral food challenge; OIT = oral immunotherapy; PP = peanut protein; PSIgE = peanut-specific immunoglobulin E; PSIgG4 = peanut-specific immunoglobulin G4; SPT = skin prick test 


\section{Sublingual immunotherapy}

Comparisons between studies on sublingual immunotherapy (SLIT) are difficult because different doses and durations. ${ }^{15-19}$ However, tentative conclusions can be drawn: in many instances SLIT achieved at leasta 10 -fold increase in peanut tolerance from baseline after several years of treatment. The ARs experienced during SLIT treatment were mild and consisted mainly of oropharyngeal symptoms. Although SLIT had a better safety profile, OIT appeared to be more efficacious overall. ${ }^{19}$

\section{Epicutaneous immunotherapy}

The early trials of epicutaneous immunotherapy (EPIT) were encouraging with at least a 10 -fold improvement in tolerated dose following 8 weeks of treatment. ${ }^{20,21}$ The safety level was high. The ARs were mostly local and mild and epinephrine injection was not required.

The efficacy, safety, and costs of OIT, SLIT, and EPIT are compared in Table 2. ${ }^{22}$ Although it is more efficacious, OIT has greater potential for ARs and is the most costly option, especially if combined with anti-IgE treatment.

\section{Update on the Hong Kong experience}

Our centre has now treated 27 peanut-allergic patients aged 6 to 16 years (22 male, 5 female) with anti-IgE and OIT, including the four children previously reported. ${ }^{11}$ Patients were considered for anti-IgE and OIT treatment if they were: aged $\geq 6$ years with a history of allergic symptoms developing within 60 minutes of peanut ingestion; serum total $\mathrm{IgE}$ between 30 and $1500 \mathrm{IU} / \mathrm{mL}$; a positive skin prick test and/or presence of peanut-specific IgE, and positive oral peanut challenge. They were of good general health with no prior exposure to monoclonal antibodies. Asthma must have been under control, with a forced expiratory volume in 1 second of at least
$80 \%$ of the predicted value. Systemic glucocorticoids, beta blockers, and angiotensin-converting enzyme inhibitors were prohibited before screening and throughout the study. Aspirin, antihistamines, and antidepressants were not permitted for 3 days, 1 week, and 2 weeks, respectively, before skin testing or oral food challenge. If potential subjects had poorly controlled asthma, poorly controlled atopic dermatitis, or inability to discontinue antihistamines or other medication for skin testing and oral challenges, they were excluded. They were also ineligible if it seemed unlikely that they would comply with the treatment protocol.

The subjects received between 150 and 600 (median 375) $\mathrm{mg}$ of anti-IgE for a median of 18 weeks, as determined by baseline serum IgE concentration and body weight. ${ }^{11}$ From about 12 weeks after beginning anti-IgE pretreatment, peanuts were eaten daily at home at an initial dose determined by OFC according to our previously reported protocol. ${ }^{11}$ Updosing was supervised at biweekly intervals in the clinic for 12 to 28 (median 16) weeks (escalation phase) until an oral intake of 2000 mg PP daily was achieved, as previously described in detail. ${ }^{11}$ The parents of one child requested to stop escalation after $800 \mathrm{mg}$ of PP because they felt that he was already protected from accidental ingestion and had a strong taste aversion to peanuts. $\mathrm{He}$ continued on $800 \mathrm{mg}$ during his maintenance phase. If a patient had a major AR on an updosing visit, the next daily dose was reduced to a previously tolerated dose (often halved), and escalation proceeded more slowly (3-4 weeks) until higher doses were tolerated or the patient withdrew. Successful escalation was followed by a maintenance phase, when patients normally ingested $2000 \mathrm{mg}$ PP daily.

Twenty-three of the 27 peanut allergic children completed the escalation phase according to protocol (85\%). There were three dropouts, of which two were caused by peanut-related AR, and the third moved away from Hong Kong for family reasons. Another child stopped updosing at $800 \mathrm{mg}$, as described

TABLE 2. Comparison of OIT, SLIT, and EPIT for peanut allergy (adapted from reference 22)

\begin{tabular}{lccc}
\hline & OIT & SLIT & EPIT \\
\hline Daily maintenance dose (PP) & $133-4000 \mathrm{mg}$ & $165-3700 \mu \mathrm{g}$ & $50-250 \mu \mathrm{g}$ \\
Updosing & Every 1 or 2 weeks & Every 1 or 2 weeks & Initiation and periodic follow-up \\
Adverse reactions & Mostly minor; some severe & Minor & Minimal \\
Efficacy & Very good & Good & Ongoing investigation \\
Desensitisation & Substantial & Moderate & Ongoing investigation \\
Sustained unresponsiveness & 33\%-87.1\% & 10\%-100\% & ND \\
Long-term tolerance & Insufficient data & ND & ND \\
Costs & Expensive (very costly if combined & Less costly & ND \\
\hline
\end{tabular}

Abbreviations: anti-IgE = anti-immunoglobulin E; EPIT = epicutaneous immunotherapy; ND = no data; OIT = oral immunotherapy; $\mathrm{PP}=$ peanut protein; SLIT = sublingual immunotherapy 
already, but continued into the maintenance phase (Fig). The dose of PP tolerated at OFC increased from a median of $5 \mathrm{mg}$ at baseline to $200 \mathrm{mg}$ after antiIgE treatment and subsequently to a median of 2000 $\mathrm{mg}$ in the maintenance phase. There was a 400 -fold improvement in the median tolerated peanut dose (Table 3), yielding a final tolerance greater than the amount of peanuts likely to be encountered through inadvertent ingestion.

The immunological data are shown in Table 3. There was a marked decrease in biomarkers such as peanut-specific IgE and Ara h1, 2, and 3 (but not in Ara h 8 and 9, which were very low at baseline). Skin prick testing (SPT) and the dilution of peanut extract in extinction titration SPT also showed improvements. The level of peanut sIgG4 increased substantially, consistent with the recruitment of an IL-10/Treg pathway.

\section{Side-effects during peanut oral immunotherapy}

\section{Escalation phase}

The ARs during updosing in hospital were directly observed; those ARs experienced at home were self-reported by patients' parents. There were 18 observed and 46 reported episodes of AR to 3560 administered doses of peanut (1.8\%). Thus, $71.9 \%$ of all ARs during the escalation phase occurred at home. One episode could comprise one or more symptoms (Table 4). Most ARs were minor (Table 4) and resolved spontaneously or after administration

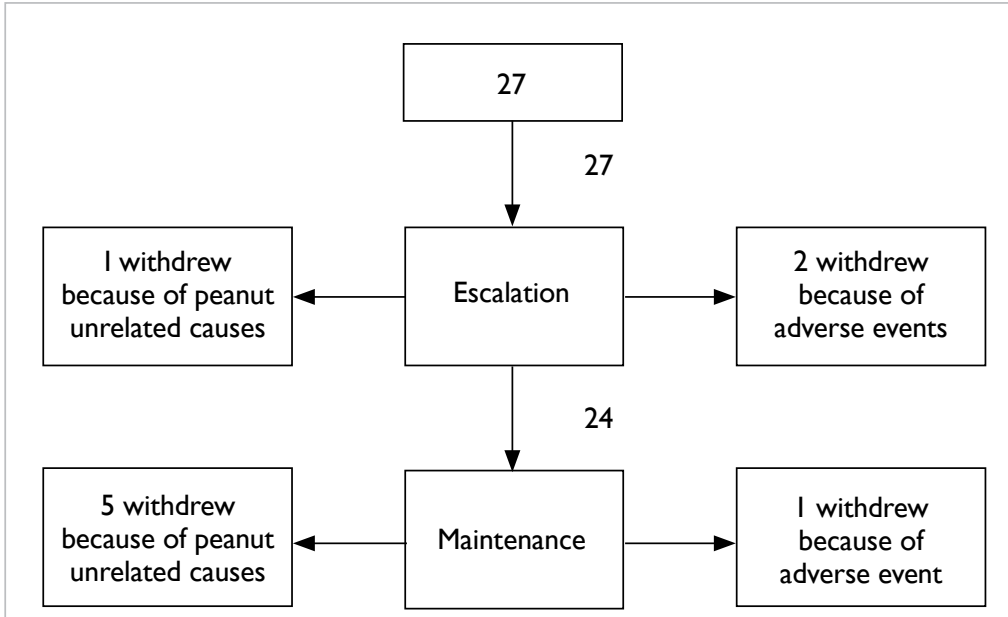

FIG. Number of patients undergoing peanut OIT of an antihistamine. One subject had 12 minor episodes but still completed escalation. There were four major episodes, which involved development of asthma, repeated vomiting, and angioedema (0.1\%), and they occurred in two patients who dropped out (Fig).

The frequent occurrence of gastrointestinal symptoms $(n=62)$ is consistent with that reported previously. ${ }^{14,23}$

TABLE 3. Immunological data during peanut OIT*

\begin{tabular}{|c|c|c|c|c|}
\hline & $\begin{array}{l}\text { Baseline median } \\
(n=27)\end{array}$ & $\begin{array}{l}\text { Post-anti-IgE } \\
\text { median }(n=27)\end{array}$ & $\begin{array}{l}\text { Maintenance } \\
\text { median }\end{array}$ & $\begin{array}{l}\mathrm{P} \text { value (Wilcoxon } \\
\text { signed rank test) }\end{array}$ \\
\hline Peanut dose (mg) & $5(n=26) \dagger$ & 200 & $2000(n=24)$ & $<0.0001 \ddagger$ \\
\hline Peanut-specific lgE (kU/L) & 28 & ND & $10.5(n=17)$ & 0.0007 \\
\hline Ara h1-specific $\lg E(\mathrm{kU} / \mathrm{L})$ & 3.5 & ND & $1.98(n=17)$ & 0.0015 \\
\hline Ara h2-specific $\operatorname{lgE}(\mathrm{kU} / \mathrm{L})$ & 26.1 & ND & $7.64(n=17)$ & 0.0005 \\
\hline Ara h3-specific $\lg E(\mathrm{kU} / \mathrm{L})$ & 0.45 & ND & $0.21(n=17)$ & 0.0016 \\
\hline Ara h8-specific $\operatorname{lgE}(\mathrm{kU} / \mathrm{L})$ & $<0.1$ & ND & $<0.1(n=17)$ & 0.2685 \\
\hline Ara h9-specific IgE (kU/L) & $<0.1$ & ND & $<0.1(n=17)$ & 0.5282 \\
\hline Peanut-specific lgG4 $(\mu \mathrm{g} / \mathrm{L})$ & 1118 & ND & $>50000(n=19)$ & $<0.0001$ \\
\hline $\mathrm{SPT}(\mathrm{mm}) \S$ & 11 & 6 & $5.5(n=24)$ & $<0.0001$ \\
\hline Peanut extinction SPTs (dilution) & 1000 & 50 & $10(n=24)$ & $<0.0001 \ddagger$ \\
\hline
\end{tabular}

Abbreviations: Ara $\mathrm{h}=$ Arachis hypogaea (peanuts); $\lg \mathrm{E}=$ immunoglobulin $\mathrm{E} ; \mathrm{ND}=$ not done; $\mathrm{SPT}=$ skin prick test

* The figures are the values at baseline; about 12 weeks after start of anti-lgE (just before the beginning of OIT) and the most recent results between 2 and 36 months of the maintenance phase depending on the stage the patient had reached. Wilcoxon signed rank test was performed to test paired pre- and post- changes between subjects $(P<0.05)$

† One family declined a baseline oral peanut challenge because of a history of very severe reactions, so the first challenge was deferred until after 12 weeks of anti-lgE treatment

‡ Comparison of post-anti-lgE data with baseline. All the other $\mathrm{P}$ values are comparisons of maintenance data with baseline values

$\S$ SPT wheal size was the mean of the sum of the two longest perpendicular diameters 
TABLE 4. Reported ARs during peanut oral immunotherapy

\begin{tabular}{lcc}
\hline Symptoms* & $\begin{array}{c}\text { No. of ARs } \\
\text { in escalation } \\
\text { phase }\end{array}$ & $\begin{array}{c}\text { No. of ARs in } \\
\text { maintenance } \\
\text { phase }\end{array}$ \\
\hline Gastrointestinal tract† & 62 & 41 \\
Skin $\ddagger$ & 22 & 23 \\
Respiratory tract§ & 4 & 18 \\
Eyes\| & 7 & 4 \\
\hline
\end{tabular}

Abbreviation: ARs = adverse reactions

* Several symptoms may occur in combination

† Includes abdominal pain, nausea, vomiting, acid reflux, diarrhoea, lip swelling, itching of lips/mouth/throat, altered taste

‡ Includes hives, rashes, angioedema, itching

$\S$ Includes coughing, rhinitis, wheezing, shortness of breath

\| Includes itching, redness

\section{Maintenance phase}

Twenty-four patients entered the maintenance phase of OIT (Fig). The duration of their maintenance phases so far has ranged from 2 to 42 (median 24) months. One child planned to study overseas and therefore continued on the maintenance doses for 6 months longer than planned (42 months in total) until he returned to Hong Kong for holidays. All parents and patients were asked to report any AR.

To date, there have been 80 reported episodes of AR from 14350 administered doses (0.6\%). The majority of subjects had no ARs, and $85 \%$ of all the ARs reported were experienced by seven $(29.2 \%)$ patients. Six of these patients were able to continue with OIT, but one patient withdrew because of severe eczema.

Forty-one, 23, and 18 side-effects reported during the maintenance phase were related to the gastrointestinal tract, skin, and respiratory system, respectively; thus, gastrointestinal symptoms predominated again (Table 4). The gastrointestinal symptoms were mostly mild and resolved either spontaneously or after antihistamine administration. Occasionally, it was also necessary to administer an oral anti-spasmodic drug.

While the incidence of AR during the maintenance phase of OIT was very low, repeated ARs still occurred in some subjects, and one episode was severe enough to warrant withdrawal from the programme. This highlights the importance of continued vigilance throughout OIT.

\section{Dropouts}

Four patients left Hong Kong for family reasons. Another two patients (twins) developed unexplained intermittent mild neutropenia after 2 years of maintenance OIT, which was not caused by peanuts. Nonetheless, although they stopped daily peanut consumption, they continued to be monitored to assess for SU. Two children were withdrawn during escalation, and one dropped out during maintenance because of peanut allergy related to AR during OIT (Fig). Thus, overall, one-third of subjects dropped out (9 of 27), but only one-third of the dropouts (3 patients; $11.1 \%$ ) withdrew because of AR caused by peanut ingestion.

The incidence of AR in our subjects was similar $^{5,9,24}$ or even lower than that in previous reports. ${ }^{6,8,10,25,26}$ Baseline allergic rhinitis and peanut SPT wheal sizes have been suggested to be significant predictors of higher overall rate of AR during peanut OIT, ${ }^{23}$ but in our series, baseline peanut SPT results; extinction dilution SPTs; peanut-specific IgE; Arachis hypogaea 1-, 2-, 3-, 8-, and 9-specific IgE concentrations; and the presence of rhinitis and asthma were not predictors of ARs $(P>0.05$ for all correlations).

\section{Preliminary data on sustained unresponsiveness}

A major concern regarding immunotherapy is whether it can induce long-term tolerance. Seven of our patients have been followed up after cessation of daily peanut consumption. Three of these subjects discontinued peanut ingestion after maintenance treatment with 1600 to $2000 \mathrm{mg}$ PP daily, and their sensitivity returned, as evidenced by ARs to intentional or accidental ingestion of peanuts as well as ARs to $100 \mathrm{mg}$ and $400 \mathrm{mg}$ PP upon OFC at 6 months $(n=2)$ and 12 months $(n=1)$, respectively. The other four subjects have continued to ingest their maintenance doses of peanuts 3 times weekly after the maintenance phase was completed and have not experienced any ARs after 4, 7, 8, and 24 months of observation, respectively.

Syed et a ${ }^{27}$ randomised 43 subjects aged 4 to 45 years to receive peanut OIT $(n=23)$ or placebo $(n=20)$. Peanut doses were escalated to $4000 \mathrm{mg}$ PP and maintained for 24 months. Then, subjects avoided peanuts for 3 months, and their SU was assessed. In all, $87 \%$ of the subjects were successfully desensitised to $4000 \mathrm{mg}$ PP, and 30\% achieved SU after avoiding peanuts for 3 months. Of the seven subjects who had SU at 3 months, only three of them (13\% of the treatment group) still achieved SU at 6 months of peanut avoidance.

\section{Conclusions}

Our protocol of combining anti-IgE with OIT is efficacious and safe, with only minor side-effects encountered by most patients. This is a retrospective record review and therefore is an audit of our realworld experience. There is growing momentum behind the development of commercial products for peanut desensitisation, ${ }^{9,10,21}$ and it is essential to compare their efficacy and safety with existing 
techniques for peanut immunotherapy in a realworld situation. ${ }^{28-30}$

Selection of suitable patients to undergo OIT is critical, as it is a labour-intensive and expensive treatment that requires time, patience, and compliance from everyone involved. We spend much time explaining the procedure in detail to the family and child to ascertain whether they are likely to complete the treatment. The patient or the patient's parent (if the patient is a child) signs an informed consent form if they agree to proceed. If they have concomitant asthma, we ensure that this is optimally controlled before embarking on OIT. Even with careful selection, four of our subjects left Hong Kong for family reasons before OIT was completed. This was unavoidable but nevertheless undesirable for the continuity of their treatment. Any treatment that takes years to complete will always be a challenge, especially for families whose children relocate for study, work, or other reasons. While some treatments can be continued by centres overseas, OIT expertise is not so easily accessible, and it may be necessary to discontinue treatment. This is regrettable, as all the parents and patients, who completed their desensitisation programmes successfully reported that their quality of life had been improved.

We recommend that this treatment only be offered by specialists with the appropriate training within an environment with immediate resuscitation facilities and support staff who are trained to manage allergic emergencies and can undertake patient education.

Our experience suggests that peanut sensitivity will likely return after a few months when OIT is stopped, so regular ingestion of peanut consumption is required to sustain the desensitised state. We now advise patients to continue consuming the maintenance dose of peanuts at least 3 times weekly to sustain desensitisation. They are seen every 6 months for skin testing, and they undergo a formal peanut challenge annually or more frequently, according to clinical judgment. We also advise that they retain their epinephrine autoinjectors for emergency treatment of unexpected events.

Alternative methods that hold promise for peanut desensitisation are being developed, including SLIT, ${ }^{15-18,20}$ low-dose OIT without antiIgE, ${ }^{6,9,31}$ co-administration of a probiotic ${ }^{7,8}$ with OIT to promote longer-term tolerance, and EPIT. ${ }^{21}$ Thus additional transformative treatments for peanut and other food allergies will be forthcoming in the near future.

\section{Author contributions}

All authors contributed to the design, acquisition of data, analysis and interpretation of data, drafting of the manuscript, and critical revision for important intellectual content. All authors also had full access to the data, contributed to the study, approved the final version for publication, and take responsibility for its accuracy and integrity.

\section{Conflicts of interest}

All authors have disclosed no conflicts of interest.

\section{Funding/support}

This research received no specific grant from any funding agency in the public, commercial, or not-for-profit sectors.

\section{Ethics approval}

The study was approved by the Hong Kong Sanatorium \& Hospital Research Committee (Ref RC-2018-27). Patients provided informed consent.

\section{References}

1. Ho MH, Lee SL, Wong WH, Ip P, Lau YL. Prevalence of self-reported food allergy in Hong Kong children and teens-a population survey. Asian Pac J Allergy Immunol 2012;30:275-84.

2. Michelsen-Huisman AD, van Os-Medendorp H, Blom WM, et al. Accidental allergic reactions in food allergy: causes related to products and patient's management. Allergy 2018;73:2377-81.

3. Sicherer SH, Burks AW, Sampson HA. Clinical features of acute allergic reactions to peanut and tree nuts in children. Pediatrics 1998;102:e6.

4. Jones SM, Pons L, Roberts JL, et al. Clinical efficacy and immune regulation with peanut oral immunotherapy. J Allergy Clin Immunol 2009;124:292-300.

5. Varshney P, Jones SM, Scurlock AM, et al. A randomized controlled study of peanut oral immunotherapy: clinical desensitization and modulation of the allergic response. J Allergy Clin Immunol 2011;127:654-60.

6. Anagnostou K, Islam S, King Y, et al. Assessing the efficacy of oral immunotherapy for the desensitisation of peanut allergy in children (STOP II): a phase 2 randomised controlled trial. Lancet 2014;383:1297-304.

7. Tang ML, Ponsonby AL, Orsini F, et al. Administration of a probiotic with peanut oral immunotherapy: a randomized trial. J Allergy Clin Immunol 2015;135:737-44.e8.

8. Hsiao KC, Ponsonby AL, Axelrad C, Pitkin S, Tang ML, PPOIT Study Team. Long-term clinical and immunological effects of probiotic and peanut oral immunotherapy after treatment cessation: 4-year follow-up of a randomized, double-blind, placebo-controlled trial. Lancet Child Adolesc Health 2017;1:97-105.

9. PALISADE Group of Clinical Investigators, Vickery BP, Vereda A, et al. AR101 oral immunotherapy for peanut allergy. N Engl J Med 2018;379:1991-2001.

10. Bird JA, Spergel JM, Jones SM, et al. Efficacy and safety of AR101 in oral immunotherapy for peanut allergy: results of ARC001, a randomized, double-blind, placebo-controlled phase 2 clinical trial. J Allergy Clin Immunol Pract 2018;6:476-85.e3.

11. Lee TH, Chan J, Lau VW, Lee WL, Lau PC, Lo MH. Immunotherapy for peanut allergy. Hong Kong Med J 2014;20:325-30.

12. Schneider LC, Rachid R, LeBovidge J, Blood E, Mittal M, Umetsu DT. A pilot study of omalizumab to facilitate rapid oral desensitization in high-risk peanut-allergic patients. J 
Allergy Clin Immunol 2013;132:1368-74.

13. MacGinnitie AJ, Rachid R, Gragg H, et al. Omalizumab facilitates rapid oral desensitization for peanut allergy. J Allergy Clin Immunol 2017;139:873-81.

14. Yee CS, Albuhairi S, Noh E, et al. Long-term outcome of peanut oral immunotherapy facilitated initially by omalizumab. J Allergy Clin Immunol Pract 2019;7:451-61. e7.

15. Kim EH, Bird JA, Kulis M, et al. Sublingual immunotherapy for peanut allergy: clinical and immunologic evidence of desensitization. J Allergy Clin Immunol 2011;127:640-6. e1.

16. Fleischer DM, Burks AW, Vickery BP, et al. Sublingual immunotherapy for peanut allergy: a randomized, doubleblind, placebo-controlled multicenter trial. J Allergy Clin Immunol 2013;131:119-27.e1-7.

17. Burks AW, Wood RA, Jones SM, et al. Sublingual immunotherapy for peanut allergy: long-term follow-up of a randomized multicenter trial. J Allergy Clin Immunol 2015;135:1240-8.e1-3.

18. Narisety SD, Frischmeyer-Guerrerio PA, Keet CA, et al. A randomized, double-blind, placebo-controlled pilot study of sublingual versus oral immunotherapy for the treatment of peanut allergy. J Allergy Clin Immunol 2015;135:127582.e1-6.

19. Pajno GB, Fernandez-Rivas M, Arasi S, et al. EAACI Guidelines on allergen immunotherapy: IgE-mediated food allergy. Allergy 2018;73:799-815.

20. Sindher S, Fleischer DM, Spergel JM. Advances in the treatment of food allergy: sublingual and epicutaneous immunotherapy. Immunol Allergy Clin North Am 2016;36:39-54.

21. Jones SM, Sicherer SH, Burks AW, et al. Epicutaneous immunotherapy for the treatment of peanut allergy in children and young adults. J Allergy Clin Immunol 2017;139:1242-52.

22. Parrish CP. Management of peanut allergy: a focus on nove immunotherapies. Available from: https://www.ajmc.com/ journals/supplement/2018/managed-care-perspectivepeanut-allergy/management-of-peanut-allergy-a-focuson-novel-immunotherapies. Accessed 15 Feb 2019.

23. Virkud YV, Burks AW, Steele PH, et al. Novel baseline predictors of allergic side effects during peanut oral immunotherapy. J Allergy Clin Immunol 2017;139:882-8. e5.

24. Vickery BP, Berglund JP, Burk CM, et al. Early oral immunotherapy in peanut-allergic preschool children is safe and highly effective. J Allergy Clin Immunol 2017;139:173-81.e8.

25. Blumchen K, Ulbricht $\mathrm{H}$, Staden U, et al. Oral peanut immunotherapy in children with peanut anaphylaxis. J Allergy Clin Immunol 2010;126:83-91.e1.

26. Yu GP, Weldon B, Neale-May S, Nadeau KC. The safety of peanut oral immunotherapy in peanut-allergic subjects in a single-center trial. Int Arch Allergy Immunol 2012;159:17982

27. Syed A, Garcia M, Lyu SC, et al. Peanut oral immunotherapy results in increased antigen-induced regulatory $\mathrm{T}$-cell function and hypomethylation of forkhead box protein 3 (FOXP3). J Allergy Clin Immunol 2014;133:500-10.

28. Wasserman RL, Hague AR, Pence DM, et al. Real-world experience with peanut oral immunotherapy: lessons learned from 270 patients. J Allergy Clin Immunol Pract 2019;7:418-26.e4.

29. Couzin-Franke J. A revolutionary treatment for allergies to peanuts and other foods is going mainstream-but do the benefits outweigh the risks? Available from: https://www. sciencemag.org/news/2018/10/revolutionary-treatmentallergies-peanuts-and-other-foods-going-mainstream-dobenefits. Accessed 16 May 2019.

30. Wasserman RL, Jones DH, Windom HH. Oral immunotherapy for food allergy: The FAST perspective. Ann Allergy Asthma Immunol 2018;121:272-5.

31. Nagakura KI, Yanagida N, Sato S, et al. Low-dose oral immunotherapy for children with anaphylactic peanut allergy in Japan. Pediatr Allergy Immunol 2018;29:512-8. 